\title{
ESTIMASI MATRIKS TRANSAKSI ANTAR SEKTOR TAHUN 2020 DI PROVINSI BANTEN
}

\section{MATRIX ESTIMATION OF THE INTER-SECTORAL TRANSACTION 2020 IN BANTEN PROVINCE}

(disubmit 14 Agustus 2021, direvisi 17 November 2021, diterima 23 November 2021)

Muhammad Fajar

BPS Provinsi Banten Jl. Syeh Nawawi Al Bantani Kav. H 1 - 2 Kawasan Pusat Pemerintahan

Prov. Banten KP3B, Sukajaya, Kec. Serang, Kota Serang, Banten 42171

Corresponding Author: mfajar@bps.go.id

\begin{abstract}
ABSTRAK
Indikator dan data ekonomi terkini, memerlukan estimasi yang mencerminkan kondisi perekonomian daerah dalam masa pandemi COVID-19. Oleh karena itu, tujuan artikel ini adalah untuk menghasilkan estimasi matriks transaksi antar sektor yang merupakan bagian dari tabel inputoutput. Data yang digunakan dalam penelitian ini adalah tabel input-output tahun 2016 dan PDRB tahun 2020 yang bersumber dari Badan Pusat Statistik Provinsi Banten. Metode yang digunakan untuk estimasi adalah matrix transformation technique. Hasil penelitian ini menunjukkan metode matrix transformation technique (MTT) mudah diterapkan dengan data yang terbatas. Matriks transaksi antar sektor hasil estimasi dengan MTT mampu menyerap informasi terkini walaupun masih ada informasi lama tentang struktur yang termuat didalamnya. Berdasarkan perbandingan antara matriks transaksi antar sektor tahun 2020 hasil estimasi terhadap matriks transaksi antar sektor tahun 2016, terlihat bahwa dampak COVID-19 menurunkan kinerja produksi pada berbagai sektor.
\end{abstract}

Kata Kunci: Input-Output, matriks, transaksi, Banten, ekonomi daerah.

\section{ABSTRACT}

The latest economic indicators and data require estimates that reflect regional economic conditions during the COVID-19 pandemic. Therefore, the purpose of this article is to produce an estimate of the inter-sectoral transaction matrix (as part of the input-output table). The data used in this study are input-output tables in 2016 and GRDP in 2020. Data source from the Badan Pusat Statistik-Statistics of Banten Province. The method used for estimation is the matrix transformation technique. The results of this study that the matrix transformation technique (MTT) method is easy to apply with limited data. The inter-sector transaction matrix estimated by the MTT can absorb the latest information. Although, there is still old information about the structure contained therein. Based on the comparison between the 2020 inter-sectoral transaction matrix and the 2016 inter-sector transaction matrix. It shows that the impact of COVID-19 has reduced production performance in various sectors.

Keywords: Input-Output, Matrix, Transaction, Banten, regional economic. 


\section{PENDAHULUAN}

Pada tahun 2020, dunia dilanda pandemi COVID-19, termasuk Indonesia. Dalam upaya pengendalian penyebaran COVID-19, otoritas pemerintah menjalankan program Pembatasan

Sosial Berskala Besar dan Pemberlakuan Pembatasan Kegiatan Masyarakat, serta penerapan sistem work from home untuk membatasi mobilitas masyarakat dan mencegah kerumunan masyakat sehingga penyebaran COVID-19 dapat ditekan. Namun, ini berimplikasi pada menurunnya aktivitas perekonomian yang tercermin pada laju pertumbuhan ekonomi pada tahun 2020 yang mengalami kontraksi -2.07 persen dibandingkan tahun sebelumnya, terlebih pada beberapa sektor yang mengalami kontraksi lebih dalam dibandingkan pertumbuhan ekonomi agregat, seperti pertumbuhan pada sektor transportasi, akomodasi dan penyediaan makan minum, transportasi, dan industri pengolahan mengalami kontraksi masing-masing sebesar 15,04\%, $10,22 \%$, dan $2,93 \%$. Hal tersebut juga terjadi pada Provinsi Banten, provinsi yang terletak di sebelah barat Ibukota Negara RI ini mengalami kontraksi ekonomi sebesar $-3,38 \%$ di tahun 2020, dimana sektor utama penopang Provinsi Banten yaitu industri pengolahan, perdagangan, dan konstruksi mengalami kontraksi yang lebih dalam dibandingkan keadaan agregat yaitu masing-masing sebesar 4,67\%, 2,86\%, dan $2,82 \%$. Laju pertumbuhan ekonomi Banten terkontraksi lebih dalam dibandingkan pertumbuhan ekonomi nasional. Ini disebabkan sektor penopang utama, yaitu industri pengolahan dan beberapa sektor lainnya mengalami kontraksi lebih dalam dibandingkan kontraksi nasional.

Efek shock tertentu terhadap perekonomian, seperti krisis, kenaikan harga, pandemic dan kebijakan tertentu dapat dikaji melalui interaksi antar sektor ekonomi dengan menggunakan tabel Input Output (IO) (Susilo dan Handoko, 2002; Chen et al., 2021; Zaidan, 2020; Imansyah, 2014; Haddad et al, 2020]. Tabel IO adalah matriks yang menyajikan informasi numerik tentang transaksi dan saling keterkaitan antar sektor dalam perekonomian, dimana masing-masing barisnya menunjukkan bagaimana output suatu sektor dialokasikan untuk memenuhi permintaan antara dan permintaan akhir, sedangkan masing-masing kolomnya menunjukkan pemakaian input antara dan input primer oleh suatu sektor dalam proses produksinya.

Pada tahun 2020, BPS Provinsi Banten telah merilis tabel IO tahun 2016, tabel IO tersebut menggambarkan perekonomian pada kondisi tahun 2016, dimana kndisi perekonomian dalam keadaan normal (tidak mengalami krisis atau pandemi), sehingga diperlukan estimasi untuk menyesuaikan ke keadaan perekonomian 2020 dan hasil estimasi tersebut dapat memberikan informasi bagi para pembuat kebijakan dalam merumuskan program dan kebijakan. 
Oleh sebab itu, dalam penelitian ini penulis melakukan estimasi matriks transaksi antar sektor yang terkandung dalam tabel IO, sesuai dengan kondisi perekonomian tahun 2020, dimana kondisi perekonomian tahun tersebut terkontraksi akibat efek COVID-19.

Adapun metode yang digunakan dalam melakukan estimasi matriks transaksi antar sektor dalam penelitian ini adalah matrix transformation technique (Wang et al, 2015; Zheng et al., 2018) dengan pertimbangan: (1) analisis time series dapat diterapkan untuk peramalan komponen IO pada tahun target, (2) metode dapat diterapkan pada periode yang sudah tersedia atau belum tersedia pada tahun target, (3) proses kalkulasi dalam metode ini lebih sederhana dan tidak menggunakan proses iterasi dibandingkan metode lainnya, seperti RAS (Stone, 1961; Stone and Brown, 1962), GRAS (Günlük-Senesen and Bates, 1988; Junius dan Oosterhaven, 2003), Cross entropy (Golan et al. (1994). Dalam penelitian ini, karena data tahun 2020 sudah tersedia, seperti PDRB berdasarkan lapangan usaha sudah tersedia, maka penulis menggunakan informasi tersebut untuk diterapkan pada matrix transformation technique (MTT).

\section{METODOLOGI}

\section{Sumber Data}

Data yang digunakan dalam penelitian adalah tabel input-output provinsi Banten transaksi domestik atas dasar harga produsen (17 sektor/lapangan usaha) tahun 2016 (dalam juta Rupiah) dan PDRB Provinsi Banten, tahun 2020 (dalam juta Rupiah). Data tersebut bersumber dari Badan Pusat Statistik. Sektor yang dimaksud adalah: A: Pertanian, Kehutanan, dan Perikanan; B: Pertambangan dan Penggalian; C: Industri Pengolahan; D: Pengadaan Listrik dan Gas; E: Pengadaan Air, Pengelolaan Sampah, Limbah dan Daur Ulang; F: Konstruksi; G: Perdagangan Besar dan Eceran; Reparasi Mobil dan Sepeda Motor; H: Transportasi dan Pergudangan; I : Penyediaan Akomodasi dan Makan Minum; J: Informasi dan Komunikasi; K: Jasa Keuangan dan Asuransi; L: Real Estate; MN: Jasa Perusahaan; O: Administrasi Pemerintahan, Pertahanan dan Jaminan Sosial Wajib; P: Jasa Pendidikan; Q: Jasa Kesehatan dan Kegiatan Sosial; RSTU: Jasa Lainnya

\section{Matrix Transformation Technique (MTT)}

Misalkan $n$ sektor ekonomi dan interaksinya direpresentasikan dalam matrix IO, yaitu:

$\boldsymbol{X}=\left[\begin{array}{cccc}x_{11} & \cdots & x_{1 n} & x_{1(n+1)} \\ \vdots & \ddots & \vdots & \vdots \\ x_{n 1} & \cdots & x_{n n} & x_{n(n+1)} \\ x_{(n+1) 1} & \cdots & x_{(n+1) n} & x_{(n+1)(n+1)}\end{array}\right]=\left[\begin{array}{cc}\boldsymbol{Z} & \boldsymbol{f} \\ \boldsymbol{v}^{\prime} & \mu\end{array}\right]$

dimana $\boldsymbol{Z}$ adalah matriks transaksi antar sektor berelemen $x_{i j}, i=1, \ldots, n ; j=1, \ldots, n$ dengan $n \times n$, $\boldsymbol{f}=\left(x_{1(n+1)}, \ldots, x_{n(n+1)}\right)^{\prime}, \boldsymbol{v}^{\prime}=\left(x_{(n+1) 1}, \ldots, x_{(n+1) n}\right)$, dan $\mu=x_{(n+1)(n+1)}=\boldsymbol{f}^{\prime} \mathbf{i}=\boldsymbol{v}^{\prime} \mathbf{i} \quad$ serta $\mathbf{i}=(1, \ldots, 1)^{\prime}$. Elemen dalam $\boldsymbol{X}$ diretriksi dan tidak dapat diprediksi secara bebas. Retriksi pada $\boldsymbol{X}$ adalah penjumlahan baris sama dengan penjumlahan kolom, sehingga berlaku: 


$$
\begin{aligned}
Z \mathbf{i}+\boldsymbol{f} & =Z^{\prime} \mathbf{i}+\boldsymbol{v} \\
\boldsymbol{f}^{\prime} \mathbf{i}+\mu & =\boldsymbol{v}^{\prime} \mathbf{i}+\mu
\end{aligned}
$$

Diasumsikan bahwa $x_{i(n+1)} \neq 0$ dan $\mu \neq 0$, kemudian $\boldsymbol{X}$ ditransformasi kedalam matriks $\boldsymbol{Y}$, yaitu:

$$
\boldsymbol{Y}=\left[\begin{array}{ll}
\boldsymbol{T} & \mathbf{i} \\
\boldsymbol{d}^{\prime} & 1
\end{array}\right]
$$

dengan:

$$
\begin{aligned}
\boldsymbol{T} & =\tilde{\boldsymbol{f}}^{-1} \boldsymbol{Z} \\
\boldsymbol{d} & =\frac{\boldsymbol{v}}{\mu} \\
\tilde{\boldsymbol{f}} & =\operatorname{diag}(\boldsymbol{f})
\end{aligned}
$$

Penulis menggunakan retriksi bahwa $\mu=$ $x_{(n+1)(n+1)}$ adalah PDRB pada tahun target (dalam hal ini tahun 2020) dan $x_{(n+1) 1} \ldots x_{(n+1) n}$ masingmasing adalah nilai tambah bruto tiap sektornya pada tahun target. Kemudian dari persamaan (3) dapat ditentukan bahwa $\boldsymbol{f}^{\prime}=\boldsymbol{v}^{\prime}$, yang berarti jumlah kolom pada sektor tertentu sama dengan jumlah baris pada sektor tertentu (sama dengan nilai tambah bruto pada sektor tertentu). Ini berimplikasi pada persamaan (1) - (4) dibawa ke tahun target, sehingga dapat direkonstruksi matriks transaksi antar sektor pada tahun target, berikut langkahnya:

1. Penulis membentuk $\tilde{\boldsymbol{f}}_{2020}$ dan $\tilde{\boldsymbol{f}}_{2020}^{-1}$ dengan menggunakan komponen PDRB menurut lapangan usaha (sektor) atas dasar harga berlaku tahun 2020 dan persamaan (7).

2. Melakukan proses penghitungan $\boldsymbol{Z}_{2020}$ dengan:

$$
\boldsymbol{Z}_{2020}=\tilde{\boldsymbol{f}}_{2020} \boldsymbol{T}_{2016}
$$

3. Lalu, melakukan evaluasi koefisien input dengan membandingkan koefisien input tahun 2016 berdasarkan tabel IO 2016 dan koefisien input tahun 2020 berdasarkan hasil estimasi. Total input pada tahun 2020 masing-masing sektor dihitung dengan menggunakan:

$$
T I_{2020}=\frac{T I_{2016} \times N T B_{2020}}{N T B_{2016}}
$$

$$
K I_{2020}=\frac{\operatorname{Kol}\left(\boldsymbol{Z}_{2020}\right)}{T I_{2020}}
$$

dengan:

$T I_{2020}$ adalah estimasi total input tiap sektor tahun 2020.

$T I_{2016}$ adalah total input tiap sektor tahun 2016 dari tabel IO 2016.

$N T B_{2020}$ adalah nilai tambah bruto tiap sektor tahun 2020 dari PDRB atas dasar harga berlaku.

$K I_{2020}$ adalah estimasi koefisien input tahun 2020.

$\operatorname{Kol}\left(\boldsymbol{Z}_{2020}\right)$ adalah tiap-tiap elemen dari kolom sektor-sektor dari $\boldsymbol{Z}_{2020}$.

\section{HASIL DAN PEMBAHASAN}

Berdasarkan proses penghitungan dengan menggunakan prosedur pada bab sebelumnya diperoleh matrik transisi antar sektor tahun 2020 yang disajikan pada Tabel 1. Matriks transaksi antar sektor tahun 2020 ini meminjam struktur interaksi antar sektor yang terkandung pada matriks transaksi tahun 2016 berdasarkan persamaan (8), namun di-update dengan informasi nilai tambah bruto setiap sektor tahun 2020 melalui $\tilde{\boldsymbol{f}}_{2020}$, sehingga informasi yang 
Tabel 1 Matriks transaksi antar sektor tahun 2020 hasil estimasi, Provinsi Banten (miliar Rp)

\begin{tabular}{|r|r|r|r|r|r|r|r|r|r|}
\hline & \multicolumn{9}{|c|}{ Kode Kategori sektor (lapangan usaha) } \\
\hline & \multicolumn{1}{|c|}{ A } & \multicolumn{1}{|c|}{ B } & \multicolumn{1}{c|}{ C } & \multicolumn{1}{c|}{ D } & \multicolumn{1}{c|}{ E } & \multicolumn{1}{c|}{ F } & \multicolumn{1}{c|}{ G } & H & I \\
\hline A & 2414,444 & 0,033 & 19887,178 & 0,032 & 0,190 & 165,114 & 5,329 & 79,755 & 3529,493 \\
\hline B & 0,000 & 287,081 & 2683,033 & 167,299 & 0,041 & 3048,017 & 1,905 & 6,744 & 0,113 \\
\hline C & 1157,044 & 20,047 & 51531,551 & 63,955 & 25,918 & 14630,257 & 3170,024 & 9898,457 & 6326,612 \\
\hline D & 6,907 & 3,370 & 5408,573 & 22316,617 & 139,046 & 137,788 & 550,074 & 473,918 & 95,790 \\
\hline E & 0,120 & 0,069 & 144,942 & 1,081 & 102,623 & 15,855 & 42,852 & 23,163 & 1,886 \\
\hline F & 54,088 & 713,145 & 1727,150 & 12,008 & 30,130 & 516,643 & 2521,626 & 1793,559 & 68,509 \\
\hline G & 611,751 & 138,734 & 18361,315 & 1340,063 & 52,927 & 5704,780 & 1272,440 & 9105,028 & 2322,141 \\
\hline H & 79,647 & 57,627 & 4179,387 & 247,156 & 17,445 & 1236,533 & 1428,196 & 11722,780 & 303,159 \\
\hline I & 1,644 & 18,809 & 588,793 & 16,115 & 4,094 & 378,609 & 357,170 & 1724,978 & 20,168 \\
\hline J & 1,974 & 10,540 & 1461,851 & 164,569 & 9,535 & 978,324 & 2228,184 & 5047,756 & 218,286 \\
\hline K & 17,188 & 33,025 & 2530,214 & 527,964 & 10,422 & 657,784 & 3430,759 & 2197,813 & 107,011 \\
\hline L & 0,002 & 43,964 & 588,240 & 0,024 & 11,125 & 145,437 & 1957,656 & 275,735 & 41,261 \\
\hline MN & 0,512 & 38,486 & 1146,972 & 573,898 & 22,364 & 599,135 & 1033,266 & 3698,789 & 63,041 \\
\hline O & 0,000 & 0,000 & 36,917 & 18,193 & 12,129 & 106,022 & 10,057 & 568,275 & 145,937 \\
\hline P & 0,665 & 0,138 & 122,230 & 7,625 & 0,059 & 71,997 & 54,492 & 250,333 & 4,026 \\
\hline Q & 1,174 & 4,083 & 261,187 & 2,963 & 0,125 & 12,043 & 85,904 & 117,992 & 4,860 \\
\hline RSTU & 24,517 & 32,454 & 1721,270 & 16,749 & 82,923 & 133,033 & 185,307 & 525,089 & 259,232 \\
\hline
\end{tabular}

Tabel 1 lanjutan

\begin{tabular}{|c|r|r|r|r|r|r|r|r|}
\hline & \multicolumn{1}{|c|}{ Kode Kategori sektor (lapangan usaha) } \\
\hline & \multicolumn{1}{|c|}{$\mathrm{J}$} & \multicolumn{1}{c|}{$\mathrm{K}$} & \multicolumn{1}{c|}{$\mathrm{L}$} & \multicolumn{1}{c|}{ MN } & \multicolumn{1}{c|}{ O } & \multicolumn{1}{c|}{ P } & \multicolumn{1}{c|}{ Q } & RSTU \\
\hline A & 0,000 & 0,232 & 0,000 & 0,000 & 85,122 & 6,893 & 168,843 & 79,916 \\
\hline B & 0,758 & 0,843 & 0,523 & 0,255 & 0,989 & 0,640 & 0,167 & 0,160 \\
\hline C & 1064,908 & 208,076 & 415,801 & 73,211 & 337,518 & 999,816 & 587,498 & 676,763 \\
\hline D & 381,538 & 43,203 & 31,362 & 150,358 & 93,518 & 102,635 & 74,919 & 58,042 \\
\hline E & 5,494 & 0,725 & 1,106 & 1,424 & 5,718 & 5,718 & 28,890 & 9,072 \\
\hline F & 852,212 & 196,289 & 10103,302 & 159,255 & 315,584 & 286,807 & 59,565 & 62,293 \\
\hline G & 374,017 & 98,187 & 183,780 & 326,398 & 205,375 & 317,034 & 396,361 & 281,736 \\
\hline H & 385,702 & 117,003 & 493,401 & 925,052 & 1518,911 & 412,430 & 109,030 & 60,920 \\
\hline I & 51,533 & 19,548 & 5,446 & 90,440 & 314,719 & 135,736 & 68,487 & 32,152 \\
\hline J & 3851,896 & 450,509 & 463,477 & 610,617 & 228,668 & 1381,737 & 211,761 & 254,471 \\
\hline K & 423,515 & 663,550 & 616,410 & 265,779 & 114,707 & 103,758 & 113,700 & 151,053 \\
\hline L & 157,427 & 99,130 & 606,873 & 316,909 & 252,330 & 539,865 & 40,527 & 115,540 \\
\hline MN & 410,089 & 456,053 & 281,380 & 138,331 & 527,720 & 346,686 & 90,492 & 86,896 \\
\hline O & 231,605 & 114,045 & 2776,906 & 807,565 & 40,336 & 33,360 & 14,058 & 2,610 \\
\hline P & 137,321 & 78,732 & 0,231 & 169,093 & 32,551 & 154,473 & 50,256 & 19,335 \\
\hline Q & 0,900 & 20,526 & 32,304 & 95,160 & 1,297 & 232,725 & 58,885 & 28,002 \\
\hline RSTU & 455,559 & 29,390 & 81,141 & 227,815 & 36,644 & 84,766 & 53,248 & 197,559 \\
\hline
\end{tabular}

terkandung dalam matriks transaksi tahun 2020 dialokasikan untuk memenuhi permintaan antara mengandung mixed information. Matriks di sektor 4. Jika matris transaksi dilihat menurut transaksi antar sektor ini mencerminkan kolom, $x_{14}$ menunjukkan besarnya input yang transaksi faktor antara. Misalkan elemen $x_{14}$, digunakan oleh sektor 4 yang berasal dari jika dilihat menurut baris maka angka tersebut sektor 1. menunjukkan besarnya output sektor 1 yang 
Tabel 2 Input Antara Domestik tahun 2020 hasil estimasi, Provinsi Banten (miliar Rp)

\begin{tabular}{|c|r|r|}
\hline Sektor & Input Antara Domestik & \multicolumn{1}{|c|}{ Share $(\%)$} \\
\hline A & 4371,675 & 1,470 \\
\hline B & 1401,603 & 0,471 \\
\hline C & 112380,803 & 37,791 \\
\hline D & 25476,312 & 8,567 \\
\hline E & 521,096 & 0,175 \\
\hline F & 28537,371 & 9,596 \\
\hline G & 18335,239 & 6,166 \\
\hline H & 47510,165 & 15,976 \\
\hline I & 13511,526 & 4,544 \\
\hline J & 8784,473 & 2,954 \\
\hline K & 2596,041 & 0,873 \\
\hline L & 16093,442 & 5,412 \\
\hline MN & 4357,661 & 1,465 \\
\hline O & 4111,706 & 1,383 \\
\hline P & 5145,079 & 1,730 \\
\hline Q & 2126,686 & 0,715 \\
\hline RSTU & 2116,519 & 0,712 \\
\hline Total & 297377,398 & 100,000 \\
\hline
\end{tabular}

Jika matriks transaksi dijumlahkan per kolom lapangan usaha, diperoleh input antara domestik tiap sektor. Input antara domestik adalah input yang digunakan dalam proses produksi (sekali habis terpakai) yang berasal dari ouput sektor-sektor lainnya dalam domestik wilayah tersebut.

Jika matriks transaksi dilihat input antara domestik, diketahui bahwa sektor industri pengolahan membutuhkan input antara terbesar dari domestik untuk menghasilkan outputnya (lihat Tabel 2) sebesar Rp112,38 triliun, disusul sektor transportasi dan pergudangan, dan sektor konstruksi masing-masing sebesar Rp47,51 triliun dan Rp28,54 triliun. Pada tahun 2020 (pada masa pandemi COVID-19), sektor industri pengolahan merupakan sektor penopang utama bagi perekonomian Banten dengan kontribusi sebesar $31,21 \%$, disusul sektor perdagangan dan sektor konstruksi masing-masing berkontribusi pada perekonomian Banten sebesar 13,33\% dan $11,43 \%$.

Dari matriks transaksi antar sektor pada Tabel 1 dapat dihitung koefisien input dengan menghitung input antara impor luar negeri dan impor antar provinsi untuk memperoleh total input antara, serta ditambah komponen nilai tambah bruto setiap sektor, yang informasinya tersedia secara rutin pada PDRB (Produk Domestik Regional Bruto) sehingga penjumlahan dari total input antara dan nilai tambah bruto adalah total input.

Dalam artikel ini, penulis mengestimasi dengan menggunakan proporsi atau struktur nilai tambah bruto dan total input antara terhadap total input tahun 2020 dari informasi tabel IO 2016 Provinsi Banten dan PDRB Banten, sehingga dapat diestimasi total input (baik penyusunnya input antara impor luar negeri dan impor antar provinsi). Matriks koefisien input (koefisien input yang dimaksud adalah elemen matriks transaksi antar sektor dibagi dengan total input pada kolom sektor yang bersesuaian) tahun 2020 Provinsi Banten yang disajikan pada tabel 3.

Pada Tabel 3, nilai koefisien input berada dalam range $[0,1]$. Sebagai contoh interpretasi 
Tabel 3 Matriks Koefisien Input tahun 2020 hasil estimasi, Provinsi Banten

\begin{tabular}{|c|c|c|c|c|c|c|c|c|c|c|}
\hline & $\mathrm{A}$ & $\mathrm{B}$ & $\mathrm{C}$ & $\mathrm{D}$ & $\mathrm{E}$ & $\mathrm{F}$ & $\mathrm{G}$ & $\mathrm{H}$ & $\mathrm{I}$ & $\mathrm{J}$ \\
\hline $\mathrm{A}$ & 0,048135 & 0,000004 & 0,043977 & 0,000000 & 0,000109 & 0,001437 & 0,000055 & 0,000431 & 0,080199 & 0,000000 \\
\hline $\mathrm{B}$ & 0,000000 & 0,039449 & 0,005933 & 0,002297 & 0,000024 & 0,026526 & 0,000020 & 0,000036 & 0,000003 & 0,000022 \\
\hline $\mathrm{C}$ & 0,023067 & 0,002755 & 0,113953 & 0,000878 & 0,014817 & 0,127322 & 0,032696 & 0,053454 & 0,143756 & 0,031315 \\
\hline $\mathrm{D}$ & 0,000138 & 0,000463 & 0,011960 & 0,306399 & 0,079491 & 0,001199 & 0,005673 & 0,002559 & 0,002177 & 0,011220 \\
\hline $\mathrm{E}$ & 0,000002 & 0,000010 & 0,000321 & 0,000015 & 0,058668 & 0,000138 & 0,000442 & 0,000125 & 0,000043 & 0,000162 \\
\hline $\mathrm{F}$ & 0,001078 & 0,097995 & 0,003819 & 0,000165 & 0,017225 & 0,004496 & 0,026008 & 0,009686 & 0,001557 & 0,025060 \\
\hline $\mathrm{G}$ & 0,012196 & 0,019064 & 0,040603 & 0,018399 & 0,030258 & 0,049647 & 0,013124 & 0,049169 & 0,052765 & 0,010998 \\
\hline $\mathrm{H}$ & 0,001588 & 0,007919 & 0,009242 & 0,003393 & 0,009973 & 0,010761 & 0,014730 & 0,063306 & 0,006889 & 0,011342 \\
\hline I & 0,000033 & 0,002585 & 0,001302 & 0,000221 & 0,002341 & 0,003295 & 0,003684 & 0,009315 & 0,000458 & 0,001515 \\
\hline $\mathrm{J}$ & 0,000039 & 0,001448 & 0,003233 & 0,002259 & 0,005451 & 0,008514 & 0,022982 & 0,027259 & 0,004960 & 0,113270 \\
\hline $\mathrm{K}$ & 0,000343 & 0,004538 & 0,005595 & 0,007249 & 0,005958 & 0,005724 & 0,035385 & 0,011869 & 0,002432 & 0,012454 \\
\hline $\mathrm{L}$ & 0,000000 & 0,006041 & 0,001301 & 0,000000 & 0,006360 & 0,001266 & 0,020191 & 0,001489 & 0,000938 & 0,004629 \\
\hline $\mathrm{MN}$ & 0,000010 & 0,005288 & 0,002536 & 0,007879 & 0,012785 & 0,005214 & 0,010657 & 0,019974 & 0,001432 & 0,012059 \\
\hline $\mathrm{O}$ & 0,000000 & 0,000000 & 0,000082 & 0,000250 & 0,006934 & 0,000923 & 0,000104 & 0,003069 & 0,003316 & 0,006811 \\
\hline $\mathrm{P}$ & 0,000013 & 0,000019 & 0,000270 & 0,000105 & 0,000034 & 0,000627 & 0,000562 & 0,001352 & 0,000091 & 0,004038 \\
\hline $\mathrm{Q}$ & 0,000023 & 0,000561 & 0,000578 & 0,000041 & 0,000071 & 0,000105 & 0,000886 & 0,000637 & 0,000110 & 0,000026 \\
\hline RSTU & 0,000489 & 0,004460 & 0,003806 & 0,000230 & 0,047406 & 0,001158 & 0,001911 & 0,002836 & 0,005890 & 0,013396 \\
\hline Jumlah & 0,087155 & 0,192598 & 0,248510 & 0,349780 & 0,297905 & 0,248352 & 0,189110 & 0,256566 & 0,307015 & 0,258319 \\
\hline
\end{tabular}

Tabel 3 Lanjutan

\begin{tabular}{|c|c|c|c|c|c|c|c|}
\hline & $\mathrm{K}$ & $\mathrm{L}$ & $\mathrm{MN}$ & $\mathrm{O}$ & $\mathrm{P}$ & $\mathrm{Q}$ & $\mathrm{RSTU}$ \\
\hline $\mathrm{A}$ & 0,000011 & 0,000000 & 0,000000 & 0,005142 & 0,000302 & 0,015612 & 0,006327 \\
\hline B & 0,000042 & 0,000008 & 0,000014 & 0,000060 & 0,000028 & 0,000015 & 0,000013 \\
\hline C & 0,010256 & 0,006660 & 0,003930 & 0,020390 & 0,043763 & 0,054322 & 0,053584 \\
\hline D & 0,002129 & 0,000502 & 0,008072 & 0,005650 & 0,004492 & 0,006927 & 0,004596 \\
\hline E & 0,000036 & 0,000018 & 0,000076 & 0,000345 & 0,000250 & 0,002671 & 0,000718 \\
\hline F & 0,009675 & 0,161825 & 0,008549 & 0,019065 & 0,012554 & 0,005508 & 0,004932 \\
\hline G & 0,004840 & 0,002944 & 0,017522 & 0,012407 & 0,013877 & 0,036649 & 0,022307 \\
\hline H & 0,005767 & 0,007903 & 0,049661 & 0,091760 & 0,018052 & 0,010081 & 0,004823 \\
\hline I & 0,000963 & 0,000087 & 0,004855 & 0,019013 & 0,005941 & 0,006332 & 0,002546 \\
\hline J & 0,022205 & 0,007424 & 0,032780 & 0,013814 & 0,060480 & 0,019580 & 0,020148 \\
\hline K & 0,032705 & 0,009873 & 0,014268 & 0,006930 & 0,004542 & 0,010513 & 0,011960 \\
\hline L & 0,004886 & 0,009720 & 0,017013 & 0,015244 & 0,023630 & 0,003747 & 0,009148 \\
\hline MN & 0,022478 & 0,004507 & 0,007426 & 0,031880 & 0,015175 & 0,008367 & 0,006880 \\
\hline O & 0,005621 & 0,044478 & 0,043353 & 0,002437 & 0,001460 & 0,001300 & 0,000207 \\
\hline P & 0,003881 & 0,000004 & 0,009078 & 0,001966 & 0,006761 & 0,004647 & 0,001531 \\
\hline Q & 0,001012 & 0,000517 & 0,005109 & 0,000078 & 0,010187 & 0,005445 & 0,002217 \\
\hline RSTU & 0,001449 & 0,001300 & 0,012230 & 0,002214 & 0,003710 & 0,004923 & 0,015642 \\
\hline Jumlah & 0,127955 & 0,257769 & 0,233937 & 0,248395 & 0,225205 & 0,196639 & 0,167578 \\
\hline
\end{tabular}

makna koefisien input pada kolom A (Pertanian,

Perikanan, dan Kehutanan), adalah bahwa untuk menghasilkan 1 (satuan nilai moneter) nilai output sektor A (Pertanian, Perikanan, dan Kehutanan), dibutuhkan bahan baku (input antara) senilai 0,087155 (satuan nilai moneter); dengan rincian: 0,048135 (satuan nilai moneter) untuk bahan baku dari sektor A (Pertanian, Perikanan, dan Kehutanan), 0,023067 (satuan nilai moneter) untuk bahan baku dari sektor $\mathrm{C}$ (Industri Pengolahan), 0,002129 (satuan nilai moneter) untuk bahan baku dari sektor $\mathrm{D}$ (Pengadaan Listrik dan Gas), dan seterusnya. terjadi pada sektor B, C, D, E, F, G, H, I, dan
Atas dasar itu, koefisien input mencerminkan kombinasi penggunaan input untuk menghasilkan satu unit output.

Tabel 4 merupakan hasil matriks transaksi antar sektor tahun 2020 hasil estimasi dikurangi matriks transaksi antar sektor tahun 2016 dari tabel input output. Terdapat nilai negatif di sepanjang baris sektor B, C, D, E, F, G, H, I, dan MN yang tersebar pada semua kolom. Ini berarti semua sektor terkena imbas COVID-19 yang mewujud dalam penurunan proses produksi pada berbagai sektor dan yang terkena efek signifikan 
Tabel 4 Hasil Selisih antara Matriks Transaksi antar sektor tahun 2020 hasil estimasi dan Matriks Transaksi antar sektor tahun 20216, Provinsi Banten

\begin{tabular}{|c|c|c|c|c|c|c|c|c|}
\hline & A & B & $\mathrm{C}$ & $\mathrm{D}$ & E & $\mathrm{F}$ & G & $\mathrm{H}$ \\
\hline A & 957,3845602 & 0,0128942 & 7885,7414093 & 0,0128641 & 0,0754475 & 65,4717314 & 2,1129113 & 31,6247651 \\
\hline B & $-0,0000027$ & $-38,0704823$ & $-355,8030462$ & $-22,1859235$ & $-0,0054688$ & $-404,2044146$ & $-0,2525862$ & $-0,8943660$ \\
\hline $\mathrm{C}$ & $-46,9064500$ & $-0,8126937$ & $-2089,0844238$ & $-2,5927247$ & $-1,0507260$ & $-593,1092847$ & $-128,5124725$ & $-401,2825574$ \\
\hline $\mathrm{D}$ & $-2,0843683$ & $-1,0168873$ & $-1632,1249764$ & $-6734,4031698$ & $-41,9595227$ & $-41,5798971$ & $-165,9937659$ & $-143,0124653$ \\
\hline E & $-0,0296422$ & $-0,0171908$ & $-35,8664737$ & $-0,2676202$ & $-25,3944246$ & $-3,9234229$ & $-10,6038210$ & $-5,7317997$ \\
\hline $\mathrm{F}$ & 13,1415232 & 173,2707882 & 419,6405405 & 2,9174609 & 7,3206002 & 125,5270987 & 612,6717969 & 435,7756825 \\
\hline G & 103,1732052 & 23,3977552 & 3096,6798875 & 226,0048263 & 8,9262184 & 962,1248142 & 214,6000360 & 1535,5848842 \\
\hline $\mathrm{H}$ & $-76,8236550$ & $-55,5844117$ & $-4031,2494819$ & $-238,3959336$ & $-16,8262642$ & $-1192,7040495$ & $-1377,5741562$ & $-11307,2677280$ \\
\hline I & $-0,5035235$ & $-5,7598331$ & $-180,3088990$ & $-4,9349888$ & $-1,2538468$ & $-115,9432423$ & $-109,3777788$ & $-528,2481017$ \\
\hline $\mathrm{J}$ & 0,2389523 & 1,2759508 & 176,9658378 & 19,9220150 & 1,1542403 & 118,4320015 & 269,7349946 & 611,0610417 \\
\hline $\mathrm{K}$ & 3,3085654 & 6,3570436 & 487,0467702 & 101,6289512 & 2,0061502 & 126,6183776 & 660,3948120 & 423,0621586 \\
\hline $\mathrm{L}$ & 0,0002418 & 6,1148370 & 81,8174577 & 0,0033477 & 1,5473586 & 20,2286496 & 272,2874435 & 38,3516195 \\
\hline $\mathrm{MN}$ & $-0,2510732$ & $-18,8670818$ & $-562,2870830$ & $-281,3454010$ & $-10,9637291$ & $-293,7174861$ & $-506,5440991$ & $-1813,2801453$ \\
\hline $\mathrm{O}$ & 0,0000000 & 0,0000000 & 13,2650874 & 6,5371027 & 4,3583428 & 38,0961801 & 3,6135818 & 204,1935193 \\
\hline $\mathrm{P}$ & 0,2619642 & 0,0543971 & 48,1530438 & 3,0040725 & 0,0231335 & 28,3635882 & 21,4675084 & 98,6199799 \\
\hline Q & 0,4460700 & 1,5516522 & 99,2635146 & 1,1260082 & 0,0475271 & 4,5769198 & 32,6476020 & 44,8425356 \\
\hline RSTU & 5,7451603 & 7,6048616 & 403,3443773 & 3,9248830 & 19,4312143 & 31,1734845 & 43,4229752 & 123,0438082 \\
\hline
\end{tabular}

Tabel 4 Lanjutan

\begin{tabular}{|c|c|c|c|c|c|c|c|c|c|}
\hline & I & $\mathrm{J}$ & $\mathrm{K}$ & $\mathrm{L}$ & MN & $\mathrm{O}$ & $\mathrm{P}$ & Q & RSTU \\
\hline A & 1399,5283829 & 0,0000788 & 0,0920212 & 0,0000000 & 0,0000000 & 33,7527713 & 2,7332605 & 66,9504630 & 31,6887617 \\
\hline B & $-0,0149732$ & $-0,1004577$ & $-0,1117773$ & $-0,0693653$ & $-0,0337785$ & $-0,1311439$ & $-0,0848829$ & $-0,0220991$ & $-0,0212362$ \\
\hline $\mathrm{C}$ & $-256,4802640$ & $-43,1712739$ & $-8,4353765$ & $-16,8565276$ & $-2,9679721$ & $-13,6829439$ & $-40,5324427$ & $-23,8171272$ & 27,4359025 \\
\hline D & $-28,9063041$ & 115,1351853 & $-13,0373338$ & $-9,4640771$ & $-45,3728655$ & $-28,2205318$ & $-30,9718780$ & $-22,6080369$ & 17,5151083 \\
\hline E & $-0,4666402$ & $-1,3594555$ & $-0,1794642$ & $-0,2735905$ & $-0,3523756$ & $-1,4148529$ & $-1,4149990$ & $-7,1490128$ & $-2,2449721$ \\
\hline $\mathrm{F}$ & 16,6454113 & 207,0592859 & 47,6918576 & 2454,7689700 & 38,6936282 & 76,6763882 & 69,6847302 & 14,4723180 & 15,1351377 \\
\hline G & 391,6346583 & 63,0787901 & 16,5595019 & 30,9950022 & 55,0478197 & 34,6370605 & 53,4685026 & 66,8472010 & 47,5155105 \\
\hline $\mathrm{H}$ & $-292,4140126$ & 372,0310658 & 112,8558718 & $-475,9128717$ & 892,2640753 & 1465,0729477 & 397,8114883 & 105,1650841 & $\mathbf{5 8 , 7 6 0 2 7 8 7}$ \\
\hline I & $-6,1761629$ & $-15,7812871$ & $-5,9861667$ & $-1,6676987$ & $-27,6958806$ & $-96,3777239$ & $-41,5670034$ & $-20,9730042$ & $-9,8461638$ \\
\hline $\mathrm{J}$ & 26,4248264 & 466,2949830 & 54,5368322 & 56,1066306 & 73,9188060 & 27,6816818 & 167,2675233 & 25,6349137 & 30,8052577 \\
\hline $\mathrm{K}$ & 20,5987594 & 81,5234424 & 127,7282261 & 118,6541149 & 51,1603472 & 22,0802394 & 19,9725595 & 21,8863232 & 29,0764678 \\
\hline $\mathrm{L}$ & 5,7389702 & 21,8963249 & 13,7878307 & 84,4090057 & 44,0783574 & 35,0961535 & 75,0890733 & 5,6368989 & 16,0702367 \\
\hline $\mathrm{MN}$ & $-30,9051963$ & 201,0406441 & 223,5735991 & $-137,9426841$ & $-67,8148708$ & $-258,7073926$ & 169,9581331 & $-44,3624326$ & 42,5993440 \\
\hline $\mathrm{O}$ & 52,4384621 & 83,2208575 & 40,9787328 & 997,8034372 & 290,1757671 & 14,4937589 & 11,9868749 & 5,0515066 & 0,9378065 \\
\hline $\mathrm{P}$ & 1,5860156 & 54,0981596 & 31,0170268 & 0,0909348 & 66,6152995 & 12,8237893 & 60,8553372 & 19,7985983 & 7,6170633 \\
\hline Q & 1,8470589 & 0,3421216 & 7,8007675 & 12,2769180 & 36,1653420 & 0,4928052 & 88,4466264 & 22,3789615 & 10,6420088 \\
\hline RSTU & 60,7456074 & 106,7509405 & 6,8869997 & 19,0137069 & 53,3837313 & 8,5867599 & 19,8632195 & 12,4774706 & 46,2939560 \\
\hline
\end{tabular}

MN. Oleh karena itu, koefisien input yang diturunkan dari matriks transaksi tahun 2020 hasil estimasi setidaknya telah menyerap informasi efek COVID-19 yang mempengaruhi kinerja produksi berbagai sektor. Walaupun demikian, perlu tambahan informasi perihal laju pertumbuhan per sektor tahun 2020 yang berguna untuk mendapatkan gambaran yang 
komprehensif, ketika menggunakan hasil estimasi matriks transaksi antar sektor dan matriks koefisien input yang tersaji pada Tabel 1 dan 3.

\section{KESIMPULAN DAN REKOMENDASI}

\section{Kesimpulan}

Berdasarkan pembahasan sebelumnya dapat ditarik kesimpulan bahwa metode matrix transformation technique (MTT) mudah diterapkan dengan data yang terbatas dalam menghasilkan estimasi matriksi transaksi antar sektor yang disajikan pada Tabel 1. Adapun matriks transaksi antar sektor hasil estimasi dengan MTT mampu menyerap informasi terkini walaupun, masih ada informasi lama tentang struktur yang termuat didalamnya. Berdasarkan perbandingan antara matriks transaksi antar sektor tahun 2020 hasil estimasi terhadap matriks transaksi antar sektor tahun 2016, terlihat dampak COVID-19 menurunkan kinerja produksi pada berbagai sektor.

\section{Rekomendasi}

Baik matriks transaksi antar sektor maupun matriks koefisien input, meminjam struktur pada kondisi perekonomian tahun 2016 dengan diretriksi oleh nilai tambah bruto dan strukturnya yang merupakan kondisi perekonomian 2020. Tentu saja idealnya juga pada struktur matriks transaksi antar merujuk ke kondisi perekonomian 2020 yang memerlukan survei, namun cara estimasi tersebut merupakan metode mixed information dengan keterbatasan data yang tersedia sehingga menghasilkan estimasi yang dapat dipertanggungjawabkan secara ilmiah.

\section{DAFTAR PUSTAKA}

Chen, R., Chaiboonsri, C. \& Wannapan, S. (2021). The Perspective of Thailand Economy After the Effect of Coronavirus19 Pandemics: Explication by Dynamic IO Models and Agent-Based Simulations. SAGE Open, 11, pp: 1-17.

Golan, A., Judge, G., \& Robinson, S. (1994). Recovering information from incomplete or partial multisectoral economic data. The Review of Economics and Statistics, 76, pp: 541-549.

Günlük-Senesen, G. \& Bates, J.M. (1988). Some experiments with methods of adjusting unbalanced data matrices. Journal of the Royal Statistical Society, Series A,151, pp: 473-490.

Haddad, E.A., Perobelli, F.S. \& Araujo, I.F. (2020). Input-output analysis of Covid-19: methodology for assessing the impacts of lockdown measures. Working Papers TD NEREUS 01-2020.

Imansyah, M.H., Suryani, S., Siregar, S., Muttaqin, H., Muzdalifah, M. (2014). Impact of global financial crises on the Indonesian economy: an input-output analysis. China-USA Business Review, Vol. 13, No. 9, pp: 573-591.

Junius, T. \& Oosterhaven, J. (2003). The Solution of Updating or Regionalizing a Matrix with both Positive and Negative Entries. Economic Systems Research, 15, pp:87-96.

Najmuddin, Z. (2020). The Impact of Government Expenditure on Banten Economic Growth in 2010 - 2017. Jurnal Perencanaan Pembangunan: The 
Indonesian Journal of Development Planning, 4(1), pp: 54-64.

Simatupang, P. \& Friyatno, S. (2016). Dampak perubahan harga bahan bakar minyak terhadap kinerja sektor pertanian (pendekatan analisis input-ouput). Jurnal Agro Ekonomi, Vol. 34 No. 1, pp: 1-15.

Sri Susilo, Y. S. \& Handoko, S. (2002). Dampak krisis ekonomi terhadap kinerja sektor industri: pendekatan model keseimbangan umum terapan Indorani. Jurnal Ekonomi dan Bisnis Indonesia, Vol. 17, No. 3, pp: $243-257$.

Stone, R. (1961). Input-Output and National Accounts. Paris, Organization for European Economic Cooperation.

Stone, R.A. \& Brown, A. (1962). A Computable Model of Economic Growth, A Programme for Growth. London, Chapman and Hall

Wang, H., Wang, C., Zheng, C., Feng, H., Guan, R., \& Long, W. (2015). Updating inputoutput tables with benchmark table series. Economic Systems Research, 27(3), pp:119.

Zheng, H., Fang, Q., Wang, C., Jiang, Y. \& Ruoen, R. (2018). Updating China's inputoutput tables series using MTT method and its comparison. Economic Modelling, 74, pp: 186-193. 